Article

\title{
Tensions in Rural Water Governance: The Elusive Functioning of Rural Water Points in Tanzania
}

\author{
Jesper Katomero ${ }^{1, *}$, Yola Georgiadou ${ }^{2}$, Juma Lungo ${ }^{3}$ and Robert Hoppe ${ }^{4}$ \\ 1 Department of Political Science and Public Administration, University of Dar es Salaam, P.O. Box 35042, \\ Dar es Salaam, Tanzania \\ 2 Department of Urban and Regional Planning and Geo-information Management (ITC), University of Twente, \\ Enschede 7500 AE, The Netherlands; p.y.georgiadou@utwente.nl \\ 3 Department of Informatics and Computer Sciences, University of Dar es Salaam, P.O. Box 35091, \\ Dar es Salaam, Tanzania; juma.lungo@zalongwa.com \\ 4 Faculty of Behavioral Management and Social Sciences, University of Twente, Enschede 7522 NB, \\ The Netherlands; r.hoppe@utwente.nl \\ * Correspondence: katomero.jesper@udsm.ac.tz; Tel.: +255-712-221-619
}

Received: 14 July 2017; Accepted: 21 August 2017; Published: 25 August 2017

\begin{abstract}
Public water services are still failing rural Tanzanians. Emboldened by advances in information communication technologies, the Ministry of Water has been developing computing, financial and administrative technologies to update and visualise the status of rural water points. This amalgam of technologies marks the emergence of an information infrastructure for rural water governance. The information infrastructure will enable the ministry to "see" the functionality status of all rural water points and to plan and budget for their repair and maintenance. In this paper, we examine three administrative technologies, which aim to standardise the functionality status of water points, and to prescribe how the information flows within the government hierarchy, and who is a legitimate recipient of this information. We analyze qualitative data, collected over a period of four years, in the framework of an interdisciplinary research program, funded by the Netherlands Organisation for Scientific Research-Science for Global Development (NWO-Wotro). In contrast to other researchers who study how information infrastructure evolves over time, we study what infrastructure evolution reveals about water governance. Our analysis of the practices of participants in rural water governance reveals tensions between formal and informal processes, which affect rural water services negatively.
\end{abstract}

Keywords: rural water governance; water points; functionality; information communication technologies (ICTs); administrative technologies

\section{Introduction}

In Tanzania, an estimated 70\% of 44 million citizens live in 12,617 villages [1]. Population increases by 1.2 million people annually, one of the fastest growth rates in the world [2]. However, public water services are still failing rural Tanzanians, despite decades of efforts to improve them [3-7]. The 2015 Millennium Development Goal assessment for access to water is "limited or no progress" [8]. Citizens depend on traditional, unimproved water sources (e.g., ponds and streams) and endanger their health and well-being [3,4,8]. A 2016 report of the Ministry of Water (MoW) shows that out of almost 88,000 rural water points $60 \%$ have "Functional", 31\% "Non Functional" and 8\% "Functional Needs Repair" status. Figure 1 illustrates how water points with a different functionality status may appear to a nearby observer. At first, a water point was simply defined as the point at which water emerges from a public improved water supply, such as a water tap [9]. Nowadays, the MoW's [10] definition is more precise: "a water point is a public tap or standpipe at which water emerges from a public 
'improved' water supply scheme. A water point can be a source by itself (e.g., a protected spring, a protected dug well or a borehole with hand pump, etc.) An 'improved' drinking-water source is one that, by the nature of its construction and when properly used, adequately protects the source from outside contamination, particularly fecal matter."

The country's rural water woes persist, despite substantial policy reforms and significant donor funding [2-5]. For instance, the National Water Policy (NAWAPO) of 2002 [11] decentralised rural water supply and transferred the ownership of water points to new village institutions, the so-called Community Owned Water Supply Organisations (COWSOs). Tanzania's Water Sector Development Program (WSDP), the largest water-sector program in Sub-Saharan Africa, attracted funding by development partners-as donors and lenders are now known - to the tune of US $\$ 1.3$ billion for its first phase (2007-2014) and is budgeted with US $\$ 3$ billion for the second phase (2015-2025). The size and organisational complexity of the WSDP makes the monitoring of the functionality status of rural water points particularly challenging $[12,13]$.

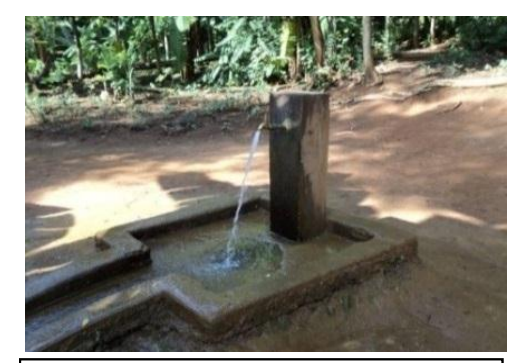

'Functional' Water Point

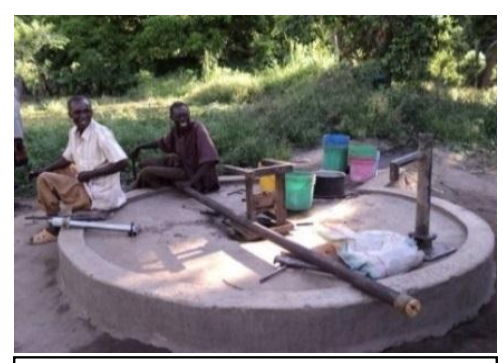

'Functional Needs Repair' Water Point

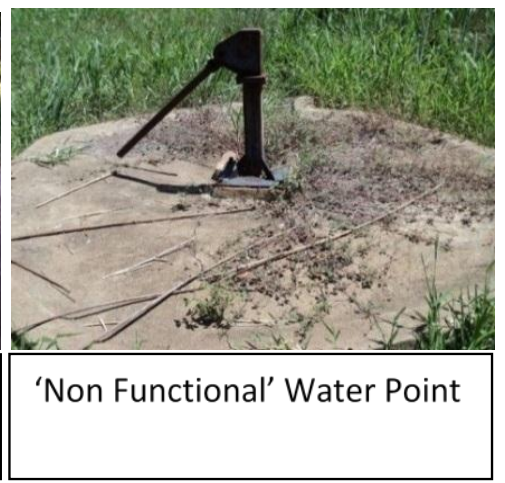

Figure 1. Images of rural water points with different functionality status adapted from [11].

In the past decade, advances in information and communication technologies (ICTs), particularly the high penetration of mobile phones, opened up new prospects for information collection and disclosure in water governance [14]. In particular, development professionals and researchers saw opportunities for quick, two-way SMS-based communication between citizens and water providers on the status of rural water points by using mobile phone-based platforms [15]. Emboldened by these prospects, the Ministry of Water developed the first ever, nation-wide, web-based information system in Sub-Saharan Africa, the so-called Water Point Mapping System (WPMS), with a World Bank loan of US $\$ 4$ million. At its most basic, a WPMS encompasses a database of baseline data on the location and status of all rural water points (Functional, Non Functional, Functional Needs Repair) at a reference epoch $\mathrm{T}$, a mechanism for the regular updating of functionality status and visualisation software. The Ministry's ambition was to "see" from distant Dar es Salaam the status of all rural water points in the nation (Figure 2), to plan and budget for their maintenance and improve the equity of future investments in rural water infrastructure in all villages across Tanzania.

Collecting baseline data for each one of about 88,000 rural water points in the country was a highly complex undertaking akin to a national census. Over a period of three years (2010-2013), the official data collectors had to interact face-to-face with thousands local informants-district water engineers, village bureaucrats, traditional village chiefs, members of village COWSOs, individual villagers and non-resident water users, such as pastoralists-in order to collect attribute data about each rural water point. Tanzania covers an area almost twice the size of France and transportation is often slow, unreliable and costly. During the rainy season, reaching villages without a canoe or a motor bike was impossible. Walking on foot for up to eight hours in order to reach a water point to collect data was common. The daily schedule of a data collector was excruciating, as he (it was always a male) commenced early in the morning and terminated at sunset. 


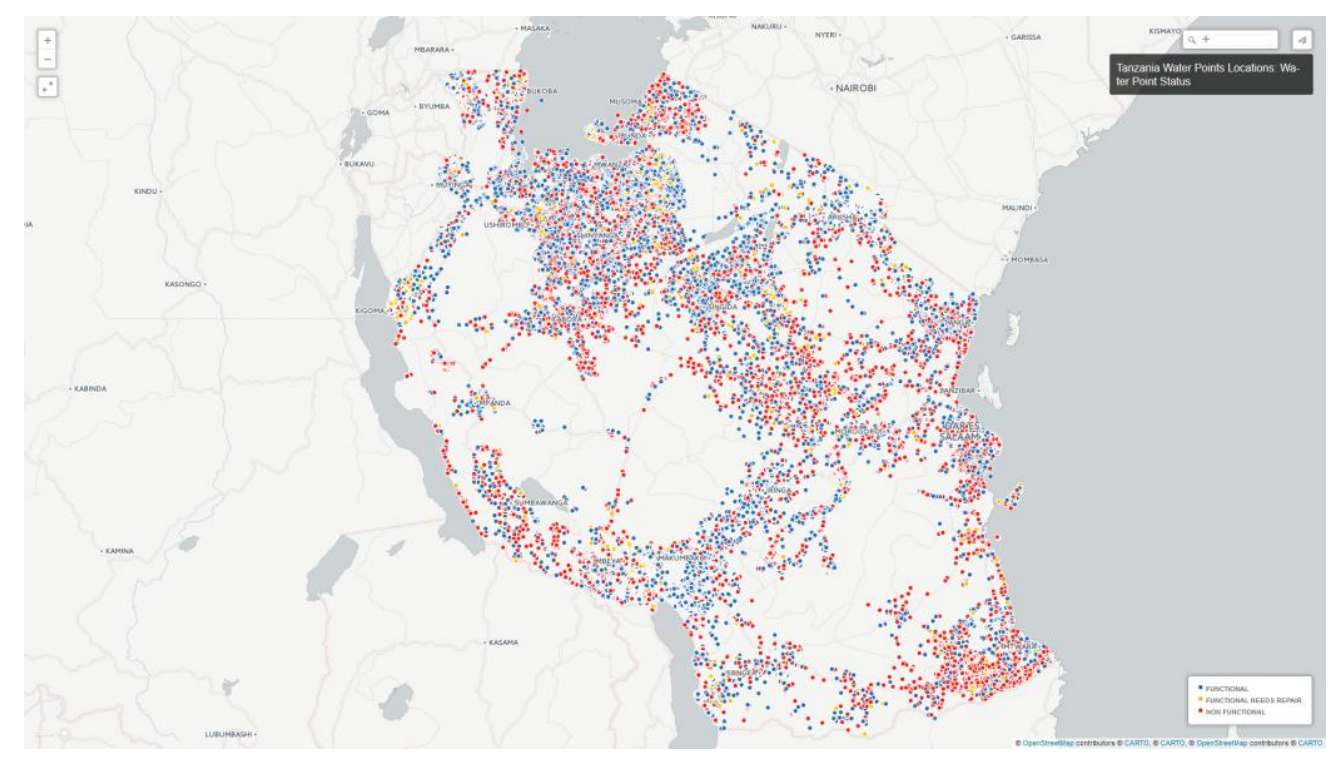

Figure 2. The current Water Dashboard of the MoW-"Seeing" the functionality status of all rural water points-Functional (blue), Non Functional (red), Functional Needs Repair (yellow) [16].

However, soon after the release of baseline data to public scrutiny in April 2013, it became clear that the data quality was far worse than the Government of Tanzania and donors had expected [17]. The water point data of entire wards within a district had either not been captured at all, or had a status of dubious quality. The other two components of the WPMS-a mechanism for regular status updating and the GIS-based visualisation software-were also developed, but were eventually cast aside, in the light of the "broken" baseline data. Ever since 2013 and to this day, the ministry, development partners, NGOs and consultants have been developing computing, financial and administrative technologies all geared towards the regular updating, the visualisation of the status and the repair of rural water points.

This amalgam of technologies-some tried and deserted, others persisting for the time being-marks the emergence of an information infrastructure for rural water governance in Tanzania. An example of computing technology is the Water Dashboard of the Ministry of Water, shown in Figure 2. An example of a financial technology is Payment-by-Results (PbR), a $£ 78$ million incentive to central and local governments of the United Kingdom Department for International Development (DFID) to repair and expand access to rural water points in 50 pilot districts. PbR will pay $£ 1500$ to local governments for each functioning water point but not for newly constructed ones. The hope is that local government will be motivated "to maintain existing water points in a sustainable manner and to fix broken water points instead of simply building new ones... Payments will be made upon an independent verification of results, building on the existing Water Point Mapping System" [18].

In this paper, we examine formal government processes embedded in three administrative technologies designed to update regularly water point (WP) functionality and inscribed in law or in official government documents. Specifically, we focus on processes aiming (1) to standardise the WP functionality status, (2) to prescribe how the information on WP functionality flows from the village to the district and, finally, to central government, and (3) to prescribe who is a legitimate recipient of this information. We collected qualitative data during a four-year period (2013 and 2017) in the framework of an interdisciplinary research program. Data include interviews with several actors in rural water supply_bureaucrats and politicians at all government levels, village leaders, data collectors, consultants and software developers. During this four-year period, our team was also developing, in cooperation with the MoW, an administrative technology-a mobile phone-based application, called the SEMA app-that enables villagers to report information on WP functionality to the district government. Thus, we were participant observers of these processes in a strong sense [19]. 
In contrast to other researchers who study how information infrastructure evolves over time, we contribute to recent STS literature, which focuses on what infrastructure evolution reveals about citizenship and governance-see [20] for an excellent overview. For example, Anand's [21] analysis of the formal and informal practices in municipal water supply in Mumbai reveals the social production of "hydraulic citizenship", a form of belonging to the city enabled by claims residents make to the city's water infrastructure. Richter's [22] study of formal and informal ways of recording information on land ownership reveals a blurred governance space between urban administration and urban society in Indian cities. Our research goal is to analyse the practices of actors, attempting to build an information infrastructure in rural water supply in Tanzania. This analysis reveals tensions between formal and informal processes, which affect rural water services negatively. We argue that the development of administrative technologies in the rural water sector should be viewed as an ongoing ecological change, where informal agency is dominant. African agency relies on informal behavior and institutions, which may either contradict the operations of formal institutions or make them more effective. The rest of the paper is organised as follows. Section 2 describes the three administrative technologies, which anchor this paper empirically. Section 3 summarizes relevant concepts and the methods used for data collection. In Sections 4 and 5, we analyze three specific processes relevant to the three administrative technologies, discuss them in view of the concepts and draw conclusions.

\section{Empirical Setting}

The release of the WPMS baseline data to public scrutiny in April 2013 unleashed a flurry of activities by the Ministry of Water, development partners (e.g., DFID and the World Bank), NGOs (e.g., WaterAid), consultants e.g., [23] and our research team. These activities focused on the development of administrative technologies geared towards the regular updating of the functionality status of rural water points as well as their repair. Three such technologies constitute our empirical setting-Big Results Now (BRN), Central Data Management Team (CDMT) and the SEMA app. We discuss them in terms of their position with respect to the Ministry of Water, the hierarchy and technology of information flow and their status (Table 1).

Launched in 2013, BRN was an attempt of the Government of Tanzania (GoT) and development partners to address the monitoring and equity of water supply, as well as of other priority areas, e.g., energy, agriculture, education, transport. In the water sector, BRN set the goal to sustain water supply to 15.2 million people, restore water supply to 5.3 million people, and extend it to 7 new million water users [24]. BRN installed a new hierarchy for the reporting of WP functionality, via new administrative units, the Ministerial Delivery Unit (MDU) and the Presidential Delivery Bureau (PDB). BRN designed a new technology for information flow, based on Google Docs [24] to simplify the reporting by the district water engineers (DWEs) to the MDU and PDB. However, the promised "synchronisation and harmonization with other monitoring systems so as to have a single source for the rural water supply sub-sector that will serve all the users" did not materialise (Water Sector Development Report [25]).

Every District Water Engineer had to send weekly updates of the WP functionality to the Ministerial Delivery Unit (MDU), without having any decision-making power within the BRN hierarchy [25]. His/her responsibility was limited to reporting WP functionality upwards. The rationale of hierarchies is to allow the rapid resolution of work-related conflicts by defining clear lines of authority. However, BRN's new hierarchy of reporting, imposed upon the existing hierarchy for monitoring rural water supply, caused confusion regarding who should do what, when and how, with what resources and authority, through which communication channels [26]. The lack of demonstrable progress and the 2015 presidential election led to the termination of BRN, when on 28 June 2017, the newly elected President of Tanzania declared the BRN defunct.

Launched in 2015, the CDMT represents yet another attempt to create a hierarchy of information flow to address the monitoring and equity of water supply. International donors in collaboration with the MoW established the CDMT under the Operations and Planning Section of the Department of Rural Water Supply (DRWS) of the MoW, to streamline and manage the flow of all data 
pertaining to the country's rural water sector [27]. Unlike the BRN, which was external to the MoW, CDMT is a new unit within the MoW. CDMT altered the existing MoW hierarchy by introducing a "project structure" [28]. It assembled old members from various MoW departments, as well as new members from outside the MoW, under a new goal—to streamline and manage the flow of all data pertaining to the country's rural water sector. The project structure enabled the ministry to resolve conflicts with respect to resources, power and authority between two former departments at the MoW—-the Information and Communication Technology (ICT) department and the DRWS-with a history of tense relations. Originally, the DRWS hosted the WPMS because it manages data on rural water supply. However, officials in the ICT department felt that they should host the system because of their ICT capacities and expertise to manage it.

CDMT chose a preformatted and partly prefilled excel-sheet as the technology of choice for the information flow. District water engineers (DWEs) must complete this template, by adding only the current functionality status of water points in their district, once every month. This was a significant improvement compared to BRN's Google Docs [24], which DWEs had to fill out from scratch every week [24]. On the 15th of each month, a DWE receives the preformatted and partly prefilled excel template for data collection via email. If the DWE has problems with data submission, CDMT officials provide him/her with remote support by phone. During each monthly reporting period, a DWE receives two reminders. The information flow is top-down, designed to collect information from lower units of governance- the DWE in the district government. A significant innovation compared to the past is the external validation of district reports by an independent inspector [10].

Table 1. Summary of three administrative technologies for the regular updating of WP functionality.

\begin{tabular}{cccc}
\hline & BRN (2013-2017) & CDMT (2015-Present) & SEMA (2014-2017) \\
\hline $\begin{array}{c}\text { Position with respect } \\
\text { to the MoW }\end{array}$ & $\begin{array}{c}\text { New units (MDU and PDB), } \\
\text { external to MoW. }\end{array}$ & New unit, but internal to MoW. & $\begin{array}{c}\text { Hybrid (VEO and/or } \\
\text { COWSO members). }\end{array}$ \\
\hline $\begin{array}{c}\text { Hierarchy of } \\
\text { information flow }\end{array}$ & $\begin{array}{c}\text { District Water Engineer } \\
\text { (DWE) reports to MDU and } \\
\text { PDB. Weekly updates. }\end{array}$ & $\begin{array}{c}\text { DWE reports to MoW/CDMT. } \\
\text { Monthly updates. Independent } \\
\text { inspector verifies the report. }\end{array}$ & $\begin{array}{c}\text { VEO and/or COWSO member } \\
\text { reports to DWE. } \\
\text { Monthly updates. }\end{array}$ \\
\hline $\begin{array}{c}\text { Technology for } \\
\text { information flow }\end{array}$ & Google Docs & $\begin{array}{c}\text { Preformatted \& partly prefilled } \\
\text { excel-template (one entry). }\end{array}$ & $\begin{array}{c}\text { Via mobile phone, numerical } \\
\text { entries to digital interface. }\end{array}$ \\
\hline Current Status & Defunct & Ongoing in all districts & Ongoing in four districts \\
\hline
\end{tabular}

How would a District Water Engineer know the functionality status of hundreds of water points in his district, unless he could inspect all of them personally on a monthly basis? Neither the BRN nor the CDMT have explicit provisions for bridging the reporting gap between the village and the district level. Deployed in 2014-2017, the SEMA app aimed to fill it. The SEMA app is a mobile phone and Unstructured Supplementary Service Data (USSD)-based administrative technology that allows COWSO members to report to DWEs on a monthly basis the functionality status of WPs in their village. The reporter in the village (e.g., a COWSO member) must answer numerically (i.e., by entering 1, 2, 3, or 4) seven simple questions (seven rows of Table 2) about each WP in the village on the screen of a standard mobile phone. The software converts the numerical answers into a status of WP functionality (eighth row of Table 2). So far, the SEMA app has been deployed in four districts. An app simulator in Swahili can be accessed by typing on the web the following address, 41.86.162.35/simulator/. The information flow in SEMA is hierarchical. At first instance, the DWE has the authority to decide whether to accept or reject the report. Ultimately, the MoW/CDMT and the independent inspector have the final say and may overrule the DWE's assessment.

However, introducing the app to COWSOs is one thing, making sure that the report is deemed legitimate by village and district bureaucrats is quite another. Demonstrations of the SEMA mobile app in one of the districts unleashed a power struggle, between DWEs, Village Executive Officers (VEOs) and COWSOs. COWSOs, the new village institutions dictated by law (Water Supply and Sanitation Act, 2009) to manage and operate rural water points, are not only inexperienced to perform their tasks, 
but also too few. "Out of 2728 planned BRN COWSO establishments by June 2014, only 460 were registered (17\%). This slowness is due to a lack of funds allocated to [district governments] for undertaking registration" (Water Sector Development Report [25]).

Table 2. The software algorithm inscribed in the SEMA app.

\begin{tabular}{|c|c|}
\hline 1 & $\begin{array}{l}\text { Does the water point have any hardware problem? } \\
\text { (1. Yes 2. No) }\end{array}$ \\
\hline 2 & $\begin{array}{l}\text { Is water flowing from water point? } \\
\text { (1. Yes 2. No) }\end{array}$ \\
\hline 3 & $\begin{array}{l}\text { What is the quality of water? } \\
\text { (1. Soft Water 2. Colored Water 3. Salt Water 4. Contains Chemicals) }\end{array}$ \\
\hline 4 & $\begin{array}{l}\text { What is the quantity of water? } \\
\text { (1. Enough 2. Not Enough 3. Seasonal) }\end{array}$ \\
\hline 5 & $\begin{array}{l}\text { Reasons for non functional water point } \\
\text { (1.Broken 2. Stolen 3. No Fuel 4. Dry) }\end{array}$ \\
\hline 6 & $\begin{array}{l}\text { Alternative water sources } \\
\text { (1. Rainfall 2. Natural Source 3. Improved Source) }\end{array}$ \\
\hline 7 & $\begin{array}{l}\text { Water point maintenance option } \\
\text { (1. Machine Service 2. Parts replacements 3. Water Leakage) }\end{array}$ \\
\hline 8 & $\begin{array}{c}\text { Water point status } \\
\text { (1. Functional 2. Non Functional 3. Functional Needs Repair) }\end{array}$ \\
\hline
\end{tabular}

\section{Concepts and Methods}

\subsection{Concepts}

To conceptualise rural water governance, we use the systems approach to organisational studies [28]. At the heart of this approach are "organisational structures"-i.e., decisions that serve as premises upon which other decisions, however complex, are routinely made within organisations. For example, the decision of a water engineer to repair a water pump in a village is not a decision premise because it applies only to this particular water pump at that time. However, when the MoW decides that the district water engineer must repair any broken water pump in his district within ten days of a break down, a decision premise comes into play. Organisational structures refer to relatively lasting patterns of order within organisations [26]. They are formal when formally decided, and informal, when informally decided. Any organisation has three types of organisational structures-programs, communication channels and members-which can be either formal or informal.

In rural water supply, formal programs include legislative acts, policies, information systems (e.g., the water point mapping system) and official documents of the Ministry of Water. They determine which formal responsibilities organisational members have and, consequently, which of their actions are to be viewed as right or wrong, and rewarded or sanctioned, respectively. The National Water Policy (2002) and related legislative acts (United Republic of Tanzania, 1982, 1998, 2009) determine the responsibilities of district officials, councillors and COWSOs in rural water supply. For instance, district officials must provide information on the status of water services in the district. Councillors must access district public records and raise questions in water-related council meetings. COWSOs must follow up on non-functional water points and mobilize communities for their revival. Informal programs may take the form of well-established, customary routines and dictate informal responsibilities, such as citizens expecting councillors to contribute their own funds for water projects.

Formal communication channels establish legitimate points of contact, proper conduits for the flow of information and domains of responsibility. They are the only means of preventing communications overkill—everybody communicating with everybody else-within an organisation. For instance, Nganyanyuka [29] describes in minute detail the formal and informal channels and legitimate points 
of contact for the information flow between a village COWSO and the district council when a rural water pump breaks down. Informal communication channels develop when formal channels are routinely bypassed, or when informal hierarchies are set up based on political party or tribal affiliations. Examples are COWSO leaders bypassing the village assembly, and instead reporting their performance to leaders of civic associations during village feasts, or citizens contacting political figures or central government public officials (not necessarily involved in the water sector) to pressure district officials to respond to their needs.

Organisational members also constitute an organisational structure because decisions that affect the organisation always depend on who occupies the position responsible for making them [28]. A COWSO or village leader who belongs to the ruling political party may decide differently from a leader who leans towards the opposition party. In the late 1960s, when Julius Nyerere massively resettled peasants to newly formed villages, peasants often chose petty-capitalist farmers as village leaders "on the assumption that they were better equipped to deal with officials, including protecting them from government interventions that would threaten their livelihood. In places where there were no such petty-capitalists, villagers often chose individuals known not to be interested in change" [30], emphasis in original), but people whose interest in interfering with their life was small. Informal members are individuals and institutions outside the formal rural water hierarchy and include political patrons, the Church, Islamic institutions, and grassroots civic associations.

Informality may be either compatible with formality, or it may break the formal rules or it may break the law. The systems approach to the study of organisations teaches that informality cannot be suppressed by decree; it can take different forms only when changes are made to the formal structures themselves [28]. A change of formal rules and procedures will not supress informality. Instead, it may lead to new informal structures that are more (or less) conducive to improvement of rural water services at the district and village levels.

\subsection{Methods}

We used a qualitative case study design to examine how administrative technologies were used for the regular updating of WP functionality through space and time. We collected data on these processes during a four-year period (2013 and 2017), in the framework of an interdisciplinary research program, called Sensors, Empowerment, and Accountability (SEMA). Our qualitative data include interviews with bureaucrats at all government levels, politicians, village leaders, data collectors and software developers. During this period, we were also developing an administrative technology-a mobile phone-based application, called SEMA app-that enables villagers to report information on WP functionality to the district government. Thus, we were participant observers in the strong sense of these processes. A key element of the overall SEMA research design was action research, which included designing the SEMA app, deploying it in a district, learning from the deployment, redesigning and repeating the testing cycle in the same district.

We conducted interviews with political and administrative officials at the national and local government levels. We used a semi-structured interview guide, organised around the themes of rural water governance, information collection and flow, analysis and usage, the BRN programme, CDMT and the functionality of rural water points. Following [31], we organised the interview themes to accurately convey meaning to the respondents and motivate them to participate. At the MoW, we interviewed officials responsible for rural water supply, i.e., the department of rural water supply, officials in the ICT department, and officials responsible for managing the BRN programme and CDMT. At the district level, we interviewed politicians and bureaucrats in council meeting halls, district headquarters, ward and village offices, field sites and informal locations. We interviewed respondents immediately after a testing session of the SEMA app.

The second method for data collection was participant observation. Before embarking on data collection, using this method, we determined beforehand the type of information we needed to observe in the participant observation venues. We prepared a short list of things that would aid the 
observations. We observed four meetings: two in a (anonymized) district and two more at the MoW. In the district, we observed council meetings, council proceedings, district meetings and field-sites where bureaucrats interacted with politicians. We made similar observations during the introduction of the SEMA mobile app at a workshop that brought together councillors, ward officials, village officials and senior district administrative officials. At the MoW, we observed reactions to the SEMA app in workshops organised to solicit the views of MoW officials regarding its usefulness for updating the WPM system. Participant observation was useful in collecting the data because social practices are sometimes missed or hard to uncover in conventional interviews, for respondents may not mention them or may consider it silly to talk about them [32].

\section{Results}

Below we analyse three formal government processes relevant to the three administrative technologies BRN, CDMT and SEMA discussed in the previous section. These processes include national standardisation, the construction of new administrative hierarchies and the flow of WP information from reporters to recipients. The analysis reveal tensions in rural water governance, which affect rural water services negatively, and are discussed in Section 5.

\subsection{National Standardisation}

The first tension arose from efforts of the MoW to standardise the functionality status of a geo-located water point (WP), during the period 2010-2017. Standardisation is a process of simplification and abstraction that defines and communicates significant aspects of artefacts across time and space [33,34]. Standardisation enables any inspector of the water point, whether a ministry official, a district water engineer or a villager, to establish the status of the WP- "functional", "non-functional", "functional needs repair"-in exactly the same way, at any time. Without such a common standard across space and time, it would be impossible to "see" (see Figure 2) the status of all rural water points in the nation and plan and budget for their repair. Using the concepts in Section 3.1, we may say that a functionality standard combines a formal program, a communication channel and members. Together, these produce a functionality status for a WP, which remains the same across multiple, spatially distributed communities of practice.

Between 2010 and 2017, the MoW endorsed three different formal programs to standardise how a district water engineer must report the functionality status of a WP (Table 3). The first program (row 1) was recommended to the Ministry by SNV (2010)—an international NGO with substantial prior experience in water point mapping in Malawi and parts of Tanzania-and was used throughout the collection of baseline data for the WPMS, in 2010-2013, as well as for BRN. It was the least precise program of the three, but vague enough to be accepted by all. The second program (row 2) was recommended to the MoW by [23], the South African consulting company hired by DFID to assess the quality of the WPMS baseline data. We inscribed See/Saw's new formal program, which the ministry had endorsed, in the algorithm of the SEMA app (see Table 2). The Ministry announced the third program (row 3) in Dodoma in January 2017. This program is far more precise than the previous two, to ensure honest reporting of WP functionality. Honest reporting-i.e., reporting the status of water points functionality without fabrications [18] — enables the district water engineer to secure annual payments for each functional water point in his/her district and helps independent inspectors identify "gaming" by the district water engineer [10].

All three programs are conditional, "if ..., then ..." decision premises [28]. During the collection of WP baseline data for the WPMS (2010-2013), official data collectors and their local informants-district water engineer and village bureaucrats—-had to apply the formal "if ..., then ... " program in the first row of Table 1. For instance, if the WP has a hardware problem; or has been non-functional for less than six months; or non-functional for less than three months; or non-functional for more than three months, then the WP is "functional needs repair". 
However, the DWE and the village bureaucrats often applied an informal program in their interactions with the official data collectors: if a WP had been non-functional for less than three months and needed only small repairs, then they declared the WP "functional", because "small repairs usually take up to three months to fix" (interview with data collector). As a result, upon completion of the data collection in 2013, it was impossible to know whether water points recorded two to three years earlier and labelled "functional", had been actually repaired in the meantime. Village bureaucrats in several villages applied a further informal program. They often entirely concealed the existence of some water points in their villages: "The village [bureaucrats] often lied to me when I asked where the water points are. They reported having fewer water points than they actually did. They did not report water points that could be reached only by walking many hours. They hoped that by lying about existing water points, especially those far away, I would construct more water points closer to them. Obviously, they over-estimated my powers. I am only a data collector" (interview with data collector). The competition between the formal and informal programs was the root cause of the broken WPMS baseline. Data on hundreds of water points had either not been captured at all, or had a functionality status of dubious quality [18].

Table 3. Conditional formal programs for reporting the functionality status of a water point.

\begin{tabular}{|c|c|c|c|}
\hline Programs & Functional & Functional Needs Repair & Non Functional \\
\hline $\begin{array}{l}\text { 1st SNV } 2010 \\
\text { (used by BRN) }\end{array}$ & $\begin{array}{l}\text { WP yields water for at least six } \\
\text { months of the year and is being } \\
\text { used by people as a water source } \\
\text { on a day to day basis }\end{array}$ & $\begin{array}{l}\text { WP has a hardware problem; WP has } \\
\text { been non-functional less than } \\
6 \text { months; or WP has been } \\
\text { non-functional less than } 3 \text { months; or } \\
\text { WP has been non-functional more than } \\
\quad 3 \text { months. }\end{array}$ & $\begin{array}{l}\text { WP does not yield water for more } \\
\text { than six months of the year for any } \\
\text { reason (e.g., hardware problem, } \\
\text { source being dry, water quality } \\
\text { (too salty, or too much fluoride). }\end{array}$ \\
\hline $\begin{array}{l}\text { 2nd See/Saw } 2014 \\
\text { (used by SEMA) }\end{array}$ & $\begin{array}{l}\text { WP does not have a hardware } \\
\text { problem; water is flowing at the } \\
\text { time of inspection; acceptable } \\
\text { water quality (based on } \\
\text { users' perception) }\end{array}$ & $\begin{array}{l}\text { WP has a hardware problem; water is } \\
\text { flowing at the time of inspection; WP } \\
\text { abandoned due to water quality. }\end{array}$ & $\begin{array}{c}\text { The WP's source is seasonal; water } \\
\text { is not flowing at the time } \\
\text { of inspection. }\end{array}$ \\
\hline $\begin{array}{c}\text { 3rd } \\
\text { CDMT/MoW } 2017\end{array}$ & $\begin{array}{l}\text { WP does not have a hardware } \\
\text { problem; produces water within } \\
\text { five strokes for a pump or a user } \\
\text { can fill a } 20 \text { L bucket in } 2 \text { min; } \\
\text { acceptable water quality (based on } \\
\text { users' perception) and meets } \\
\text { national quality norms. }\end{array}$ & $\begin{array}{l}\text { WP has a hardware problem; does not } \\
\text { produce water within } 5 \text { strokes for a } \\
\text { pump, or a user is not able to fill a } 20 \mathrm{~L} \\
\text { bucket within } 2 \text { min; water quality is } \\
\text { not acceptable (based on users' } \\
\text { perception) or does not meet national } \\
\text { quality norms. }\end{array}$ & $\begin{array}{l}\text { WP does not provide users with } \\
\text { any water supply due to damage, } \\
\text { malfunction or restriction } \\
\text { of access. }\end{array}$ \\
\hline
\end{tabular}

Between 2014 and 2017, the Ministry and donors increased their efforts to fix the WPMS baseline. This meant increasing the pressure on district water engineers, who were already overwhelmed with existing upward-reporting requirements. A district water department must sustain vertical formal communication channels, upwards to the ruling party, the district and regional commissioners, all requiring non-harmonized reports that result in duplication. The ruling party demands water point information to explain to voters how the party is fairing in the water sector and how the election manifesto is being implemented in the district. The District and Regional Commissioners demand information on the status of rural water supply. To these, the Ministry added a new formal communication channel for WP reporting first to the BRN and, since 2016, to CDMT/MoW, a new unit within the Ministry. "We collect a lot of information, some of which is not even needed by the water department, but fulfils the requirements of the region and the MoW. [R] eporting to [several] higher levels derails [district water engineers] from focusing on other responsibilities" (interview district water engineer). At the same time, district water engineers must sustain horizontal formal and informal communication channels with other district departments, councillors and contractors as well as vertical channels downwards to village bureaucrats, COWSO members and water users, some of which display a staggering complexity. For instance, Nganyanyuka [29] describes how even the writing of a check-a tiny fraction of the entire process of detecting a failed water point and fixing it-within the district government to pay for the repair of a broken water pump may take a full week. "Usually it takes a week for the accountant to write the check. This is when I do frequent follow-ups. I have to go to [the district treasurer's] office every day and if the funds are urgently needed, I sometimes make multiple visits in a day" (District official, DWE's office). 


\subsection{New Administrative Hierarchies}

In 1998, the Government of Tanzania (GoT) promulgated a policy of decentralization by devolution ( $\mathrm{d}$ by $\mathrm{d}$ ) to give district governments the power and authority to manage their own administrative, fiscal, political and personnel affairs. The policy, often referred to as "eyes on, hands off", restricts central government, e.g., the Ministry of Water, to supervision, monitoring and coordination of national policies and priorities. Districts must act autonomously in making decisions pertaining to rural water supply, including ensuring the functionality of water points. The BRN was also supposed to be implemented within the context of decentralisation by devolution, but, in reality, it functioned informally as a centralization program, in tension with the formal decentralization program.

The new administrative hierarchies, created by BRN, overburden district officials, as respondents affirmed: "we feel overburdened by the information collection roles and reporting to higher levels ... the BRN programme introduced new reporting formats and information collection formats that are confusing and impossible to handle especially in the context where internet services are poorly available in the district. In addition, there are too many reporting levels that are not coordinated" [26]. Further, reporting the functionality status of rural WP upwards is one thing; ensuring that the reported information translates into repairs is quite another, and creates further competition between the decentralization and centralisation programs, and tensions at various levels of the hierarchy in the rural water sector. For instance, the formal decentralization program instructs COWSOs to cover O\&M costs when a water point is broken. In practice, COWSO members cannot meet the costs for operation and maintenance. In response, the MoW transfers resources to districts to help fix broken water points, which are often spent for other purposes [29].

As a result, informal centralization becomes the rule. A senior official in the MoW noted: "public officials in the MoW transfer a lot of responsibilities to district authorities without [them having] adequate resources. As a result, broken rural water points are not repaired on time, and, when they are repaired, they are not repaired effectively ... " Another senior respondent in the MoW explained that: "there are not enough qualified professionals at the village and ward levels in the districts posing challenges to the implementation of various programmes in the rural water supply sector." Echoing these remarks, a senior district official noted that "BRN is like a father, who refuses to give his children better health, education, and water but expects them to live a decent life ... instead of calling it a BRN Programme, I would call it a Small Results Now Programme... you cannot have a cow producing a lot of milk, if you don't feed the animal properly" [26]. Respondents have mixed feelings regarding the financial resources required to sustain the functionality of rural water points. Central government, through the MoW, controls resources for managing rural water supply and deprives lower levels of government, including the district governments, of their autonomy. Furthermore, central government fails to disburse resources when and where needed.

Further tensions are evident between district water officials and Community Water Supply Organisations. COWSOs are formally responsible for the functionality of the water points in the village and must mobilize resources to sustain them. In reality, they lack organisational and financial management skills. A district water official explained: "A review of planning for OEM in the audit report of 2015 revealed that most of the COWSO have not quantified their O\&M costs and made no decisions on how much to charge for water to recover costs. The lack of a financial management plan to recover OEM cost and insufficient sensitization negatively impact sustainability". As a survival strategy, district officials weaponize the formal decentralization policy to dump responsibilities to COWSOs through O\&M mandates. However, COWSOs insist that the district should intervene especially when the problems-e.g., the choice of water point technology and financial disbursements-emanate from the district. While dumping responsibility is largely prevalent, our fieldwork revealed an increasing focus on repairing newly constructed water points. This practice goes hand in hand with reporting upward information regarding newly constructed water points. Old water points do not get a lot of attention from district water officials because they do not attract funds from donors. Overall, in the midst of the described 
tensions, informal centralization between the MoW and districts and COWSO and district officials determines largely which actions are taken to repair a broken water point.

The CDMT administrative technology for information flow is top-down, designed to collect information from lower units of governance, the VEOs, WEOs, and DWEs. However, CDMT adds another layer of work to VEOs, WEOs and DWEs in addition to their daily reporting routines via the WPMS. This situation, at times, results in DWEs sending incomplete, inaccurate as well as unreliable information. For instance, a CDMT report of 2016 notes that "several challenges have been seen during analysis of the data received from every [local government]. This leads to either data being rejected, or being seen as (Data Error) or as partially updated. Additional water points have no name such as in [cites examples]. Several water points have no coordinates [or] are left unfilled with no proper explanation [cites example]. Copying and pasting the old template [cites examples]. The use of old template [cites example]. Filling up status with wrong data on water taps that are not conforming to approved standards hence (data error) like [cites examples]. Incomplete filling of the status and number of taps hence partially updated."

Although CDMT argues that the quality of data collected is improving, our interviews with district officials involved with BRN reporting structures, which is replicated by CDMT by involving VEOs and WEOs, confirm that the layer after layer of hierarchical upwards reporting is confusing and derails lower government officials from performing their daily tasks. Recognizing this shortcoming, our respondent(s) informed us that CDMT now uses an informal communication channels to communicate with VEOs and WEOs to verify and crosscheck the information reported by DWEs to the MoW.

\subsection{Recipients and Reporters of WP Information}

As noted in Section 2, the SEMA mobile app sought to bridge the reporting gap between the village and the district level, by empowering COWSOs to report to the district the status of water points in their respective locality. District water officials would use the reported information to report further upwards, to the MoW, the status of water points. However, reporting and receiving information using the SEMA app generates tensions. First, DWEs as the formal recipients of WP information, compete with the desire of other actors (e.g., Councillors and COWSOs) to informal receive the WP information. Second, the formal administrative mandates of VEOs to report information on functionality/non-functionality of water points compete with the informal mandate of COWSOs to report the information.

Regarding the first tension, district councillors argued that they are entitled to the information collected with the SEMA app: "We want to receive information from the SEMA app on rural water point functionality... We need this information in order to understand the status of water points in or respective wards so that we can take political action." Similarly, COWSO members wanted to receive the information. A COWSOs chairperson pointed out: "As an organisation responsible for managing rural water points in our villages, we certainly have a right to receive the information generated by the app ... This will enable us be sure that our problems regarding the rural water points in the villages have reached the district level." However, district officials were weary of a radical information transparency to all involved. A senior district official explained that the "SEMA mobile app is a working/administrative tool for the DWE and technical people in the water department. Politicians including councillors are therefore not part of this design. If councillors and COWSOs want information, they can get it at the Ward Development Committees (WDC) where councillors serve as chairpersons and COWSOs join as members of these committees. Hence, they have access to all the information, including water point status information" [29]. However, councillors insisted that they need information to be able to question the performance of the DWE in their respective wards. The fact that district officials wanted to exclude councillors and COWSOs from receiving information from the SEMA app raises questions with regard to the role of data transparency in monitoring rural water services using mobile phones. Councillors blocked from accessing information from the SEMA app cannot scrutinize the actions and inactions of public officials. COWSOs blocked from access will not be able to know whether water points with functionality problems are attended to by the district. 
As for the second tension, COWSOs and councillors felt that the secretary general of a COWSO should report, while district water officials were adamant that the Village Executive Officers (VEO) should report. Notably, the URT constitution of 1977 and the local government laws of 2000 formally recognize the role of the VEO. From a legal perspective, both entities draw their mandate from national laws. However, the district water officials were in favour of the Village Executive Officers because VEOs provide an important administrative link between the district officials and villages. VEOs are salaried officials and reporting is their basic responsibility. They are directly accountable to the District Executive Director (DED) and the DWE. Accordingly, from the point of view of district officials, VEOs should report. Relying on VEOs as the main reporters would make things easier for the DWE because, in practice, most of the VEOs are loyal to higher administrative ranks of the district and easy to control. In defending the VEOs as the main reporters in the SEMA app, a respondent explained: "In the rural water sector, the administrative hierarchy starts with the MoW, DED, DWEs, WEOs and VEOs. Bypassing these formal administrative arrangements in reporting information violates the local government legislation of 2000, including the local government Acts of 1982 and subsequent legislations ... VEOs are not political officials, they are an important link of the administrative machinery of the district."

However, some district officials were against the idea of using VEOs as reporters on the grounds that VEOs have a lot of administrative roles and responsibilities. Respondents noted that "the district lacks funds to employ new VEOs, most of the VEOs, now working, in the district are serving in acting capacities in the villages. They are not employed by the district hence not directly accountable to the district. In some villages, VEOs are literally non-existent. The district does not have enough money to employ new VEOs." On the other hand, COWSO leaders were in favor of reporting themselves because: "COWSOs are autonomous legal entities; they are supposed to be independent to manage water points on their own without interference. Likewise, the councillors echoed this position by arguing that the roles of COWSOs and the VEO and the district are very clear ... COWSOs should send reports to VEO but should be able to report directly to the district ... the main reporter should be the COWSO secretary general." The technical staff of the department of the rural water supply challenged this idea: "Technical staff makes field visits to inspect water points and gets paid. Shifting this responsibility to COWSOs means no incomes for themselves and their families." This situation resulted in a clear tension between formal administrative mandates of VEOs to report information on functionality/non-functionality of water points and the informal mandate of COWSOs to report the information. Notably, VEOs are formerly recognized legally as part of the administrative hierarchy of the district. COWSOs are legal entities but not formally recognized in the administrative hierarchy of the district.

\section{Discussion}

The data analysis reveals five tensions in rural water governance in Tanzania caused by the competition of formal programs and communication channels with informal programs and informal communication channels. Table 4 summarizes tensions and their effects on rural water governance.

Below, we discuss the tensions and their effects on rural water governance as they pertain to standardisation, new administrative units, and, last but not least, recipients and reporters of WP information. The tensions are the following: (1) formal standardisation versus informal programs for determining WP functionality; (2) formal decentralization versus informal centralization of roles and responsibilities; (3) excessive top-down vertical communication versus indifference to complexity of horizontal communications; (4) DWEs as only formal recipients of WP information versus other actors (e.g., Councillors and COWSOs) as informal recipients of WP information; and, (5) formal administrative mandates of VEO to report functionality of water points versus the informal mandate of COWSOs to report the information. 
Table 4. Tensions between formal and informal programs and communication channels and their effects.

\begin{tabular}{|c|c|c|c|}
\hline & & Tensions & Effects \\
\hline Programs & (2) & $\begin{array}{l}\text { A series of formal standardisation } \\
\text { programs versus informal programs for } \\
\text { determining WP functionality } \\
\text { Formal decentralization versus informal } \\
\text { centralization of roles } \\
\text { and responsibilities }\end{array}$ & $\begin{array}{l}\text { "Broken" WPMS baseline Transferring of roles and } \\
\text { responsibilities to resource-less districts to manage the } \\
\text { rural water points, with unattended broken water } \\
\text { points as a result }\end{array}$ \\
\hline $\begin{array}{l}\text { Communication } \\
\text { Channels }\end{array}$ & (5) & $\begin{array}{l}\text { Excessive, top-down vertical } \\
\text { communication versus indifference to } \\
\text { complexity of } \\
\text { horizontal communications } \\
\text { DWEs as only formal recipients of WP } \\
\text { information versus the desire of other } \\
\text { actors (e.g., Councillors and COWSOs) } \\
\text { to be informal recipients of } \\
\text { WP information } \\
\text { Formal administrative mandates of } \\
\text { VEO to report information on } \\
\text { functionality/non-functionality of } \\
\text { water points versus informal mandate } \\
\text { of COWSOs to report the information }\end{array}$ & $\begin{array}{l}\text { "Broken" WPMS baseline } \\
\text { Councillors are denied the opportunity to access } \\
\text { information to hold district officials to account } \\
\text { VEOs feel bypassed and powerless. Dump } \\
\text { responsibilities to COWSOs. }\end{array}$ \\
\hline
\end{tabular}

\subsection{National Standardisation}

The Ministry's repeated efforts to standardise water point functionality compete with informal programs used by district water engineers and villagers to label water points. They also compete with local interpretations of functionality, which the following example serves to illuminate. In 2014, See/Saw Consultants presented fictional WP scenarios (WPs with various hardware problems, differing water availability including seasonality, and at varying timescales) to district water engineers in four different districts and asked them to label each fictional WP. The exercise revealed a "considerable variation in district staff interpretation of WP functionality. Since the DWEs and their staff are currently responsible for updating the WPMS, these differences in understanding will have a significant impact on the data reported for the proposed PbR payments" [23].

The ministry's diverse efforts, either through the WPMS data collection exercise, or though BRN and finally through CDMT, to oblige district water engineers to report upwards downplay the complexity of the horizontal communications they have to sustain to perform their everyday work. As Georgiadou et al. [18] argue, the additional "premature load bearing" [35], or pressure on district water officials, driven by ignorance about their daily challenges, may lead to stress and a weakening or total collapse of district water capacity. A flexible standards approach to create a modular hierarchy of national, district and village-level water point datasets might release tensions between the national standardisation, required by the Ministry and development partners, and attention to local context is required [36]. Otherwise, the real functioning of rural water points will remain elusive and invisible to the government.

Standardisation is a reflexive process, constantly needing monitoring, revisions, and new standards (as we have seen in Table 3) in rural water supply. First, (in)formal programs, communication channels and members (donors, ministry, district officials, councillors, village bureaucrats, COWSOs, etc.) compete or converge with each other during the standardisation process. Second, it is important to understand how to allow each institutional level of members (ministry, or district or village level) a degree of autonomy and flexibility in order to define their own data standards while conforming to standards of the higher levels. Third, given the political nature of the standardisation process, it is important to negotiate and provide appropriate incentives to each member to engage in the process of standard setting and use. 


\subsection{New Administrative Hierarchies}

The administrative hierarchies introduced by the ministry to monitor water point functionality compete with existing ones. They create tensions at the district level-DWEs must report upwards and at the same time attend to their daily routines, which are at odds with upwards reporting. Furthermore, ensuring that the reported information is effective and enables the repair of broken water points complicates matters more because it reinforces the competition between the decentralization and centralisation programs in the rural water sector.

These tensions affect water point functionality in several ways. The WPMS baseline suffers from poor quality data, broken water points are left unattended and responsibilities are dumped to COWSOs. The MoW and district officials abdicate their technical and financial responsibilities to assist COWSOs manage rural water points. Instead, these roles and responsibilities are transferred to COWSOs, without providing them the technical and financial resources to do so. With no results to show to development partners, all actors engage in blame games. COWSOs blame the district government for failing to repair broken points, the district government blames the MoW for not transferring resources to repair broken water points, the MoW blames the central government and the development partners for delayed or insufficient disbursement of funds.

The concept of institutional bricolage can help illuminate these tensions by explaining how new administrative hierarchies interact with existing ones. In some cases, the interaction between old and new may result in total replacement or absorption of one by the other, but it may also produce a productive hybrid [37,38]. BRN and CDMT inserted new administrative hierarchies into a context where formal decentralisation already competes with informal centralisation. Informal centralisation became an instrument through which the MoW dictates to DWEs what they should do regarding reporting information on water point functionality as well as repairing broken water points. In effect, DWEs are deprived of their autonomy to make decisions and to use available resources within their localities to repair broken water points. Instead, they have to depend on technical and financial resources from the MoW, which are always in short supply.

Creating new administrative hierarchies may improve services if applied incrementally, reflecting on the existing institutional context and constantly adapting and adjusting to prevailing (in)formal programs, communication channels, and members and how they interact or compete. It is equally important to ensure that each institutional level of members enjoys a degree of autonomy and flexibility to manage rural water points, while at the same time conforming to policy and institutional directives at higher levels. This observation agrees with $[4,5]$, who discuss challenges for water governance in the rural water supply and implementing pro-poor policies in a decentralized context.

\subsection{Recipients and Reporters of WP Information}

The introduction of the SEMA app to monitor functionality of water points created tensions with existing communication channels at the two ends of reporting and receiving information. The first tension involved DWEs as the presumably only formal recipients of WP information. This competed with the desire of other actors (e.g., Councillors and COWSOs) to be informal recipients of WP information. The second tension involved formal administrative mandates of the VEO to report information on functionality/non-functionality of water points and competed with the informal mandate of COWSOs to report the information. These tensions limit the accountability of councillors to citizens. Councillors are legally mandated to hold district officials to account. Excluding them from receiving information denies them an opportunity to access information, which they could use to hold the district officials to account. Equally, when VEOs are excluded from the district administrative links of information flows, they feel bypassed and powerless. This has a direct effect on their work for they are the formally designated administrative officials linking the district and the villages.

Administrative technologies such as the SEMA app are political in nature. They negotiate and renegotiate relations between members in organisations and introduce new communication channels. This observation is in line with $[39,40]$, who argue that apps are not free of politics, since they 
re-negotiate internal bureaucratic relationships, habits and unwritten rules. In this context, apps have a transformative power; they can transform existing communication channels by creating tensions between formal and informal recipients recipient of information versus as well as between formal and informal senders of information.

As noted by [41], any digital technology, including the SEMA app should be understood as part and parcel of a social context, both emerging out of that context, impacting upon it, and gradually acquiring new, frequently unintended meanings through anticipated and unanticipated use. In other words, apps are inscribed administrative or political preferences. The two tensions with regards to receiving and sending information via the SEMA app is a clear manifestation of this observation. As Fung et al. [42] argue, we need to understand administrative technologies as an intervention in a larger political system.

We suggest a cultivation approach for the development of an information infrastructure for rural water governance, a well-established approach in the STS scholarship of information infrastructures [43]. Cultivation is more conservative than 'construction', which privileges the power of human agency in "selecting, putting together, and arranging a number of objects to form a system" [44,45]. Cultivation emphasizes the power of the material: "the tomatoes themselves must grow, just as the wound itself must heal" [44]. A cultivation approach emphasizes improvisation and the work of people in situated action [45]. The development of administrative, as well as financial and computing technologies, should not be viewed as a well-defined process with pre-configured start and end states but as an ongoing process of ecological change of design and use, characterized by "unanticipated effects" [46] and "drift" [47]. Finally, informality is the mainstay of African life and how it operates is of both intellectual and strategic significance, especially as one turns to the link between politics and development in Africa [48].

Acknowledgments: We acknowledge the financial support of the research programme "Sensors, Empowerment and Accountability (SEMA) in Tanzania" funded by the Netherlands Organisation for Scientific Research-Science for Global Development (NWO-Wotro). Discussions with and readings of the work of Prof. Goran Hyden have significantly shaped our thinking on informality. We are grateful to our informants in Tanzania who provided us with invaluable information in rural water governance and to the two anonymous reviewers for insightful comments that improved the manuscript. We also acknowledge the contribution of Dr. Anna Wesselink, who worked in the SEMA research programme as a post-doc for two years and supervised the data collected by the first author.

Author Contributions: Jesper Katomero and Yola Georgiadou analysed, conceptualized the data and wrote the paper; Juma Lungo provided the software algorithm inscribed in the SEMA app; Robert Hoppe supervised the $\mathrm{PhD}$ thesis of the first author and critically read the paper.

Conflicts of Interest: The authors declare no conflict of interest.

\section{Abbreviations}

$\begin{array}{ll}\text { BRN } & \text { Big Results Now } \\ \text { CDMT } & \text { Central Data Management Team } \\ \text { COWSOs } & \text { Community Water Supply Organisations } \\ \text { DFID } & \text { Department for International Development } \\ \text { DRWS } & \text { Department of Rural Water Supply } \\ \text { DWE } & \text { District Water Engineer } \\ \text { GoT } & \text { Government of Tanzania } \\ \text { ICTs } & \text { Information Communication Technologies } \\ \text { MDU } & \text { Ministerial Delivery Unit } \\ \text { MoW } & \text { Ministry of Water } \\ \text { NAWAPO } & \text { National Water Policy } \\ \text { NGOs } & \text { Non-Governmental Organisations } \\ \text { O\&M } & \text { Operations and Management } \\ \text { PbR } & \text { Payment by Results }\end{array}$




$\begin{array}{ll}\text { PDB } & \text { Presidential Delivery Bureau } \\ \text { SEMA } & \text { Sensors, Empowerment and Accountability } \\ \text { SMS } & \text { Short Message Service } \\ \text { SNV } & \text { Stichting Nederlandse Vrijwilligers_Dutch NGO } \\ \text { USSD } & \text { Unstructured Supplementary Service Data } \\ \text { VEO } & \text { Village Executive Officer } \\ \text { WDC } & \text { Ward Development Committee } \\ \text { WEOs } & \text { Ward Executive Officers } \\ \text { WP } & \text { Water Point } \\ \text { WPMS } & \text { Water Point Mapping System } \\ \text { WSDP } & \text { Water Sector Development Programme }\end{array}$

\section{References}

1. Chidawali, H.; Chimbwete, R. CCM Beats Opposition Despite Decline. Available online: http://www.thecitizen. co.tz/News/CCM-beats-Opposition-despite-decline/-/1840392/2560666/-/iviub/-/index.html (accessed on 25 August 2017).

2. United Nations Development Programme (UNDP). Human Development Report of 2014: Economic Transformation for Human Development. Economic and Social Research Foundation: Dar es Salaam, Tanzania; Available online: http:/ / hdr.undp.org/sites/default/files/thdr2014-main.pdf (accessed on 26 June 2017).

3. Carlitz, R. Money flows, water trickles: Understanding patterns of decentralized water provision in Tanzania. World Dev. 2017, 93, 16-30. [CrossRef]

4. Gine Garriga, R.; Perez-Foguet, A. Sustainability assessment of national rural water supply program in Tanzania. Nat. Resour. Forum 2008, 32, 327-342. [CrossRef]

5. Jimenez, A.; Perez-Foguet, A. Challenges for water governance in rural water supply: Lessons learned from Tanzania. Int. J. Water Resour. Dev. 2010, 26, 235-248. [CrossRef]

6. De Palencia, A.J.F.; Perez-Foguet, A. Implementing pro-poor policies in a decentralized context: The case of the rural water supply and sanitation program in Tanzania. Sustain. Sci. 2011, 6, 37-49. [CrossRef]

7. Therkildsen, O. Watering White Elephants: Lessons from Donor-Funded Planning and Implementation of Rural Water Supplies in Tanzania; Scandinavian Institute of African Studies: Uppsala, Sweden, 1988; Available online: http:/ / www.diva-portal.org/smash/get/diva2:277661/FULLTEXT01.pdf (accessed on 25 June 2017).

8. United Nations Children's Fund (UNICEF); World Health Organisation. Progress on Sanitation and Drinking Water: 2015 Update and MDG Assessment; World Health Organisation: Geneva, Switzerland, 2015; Available online: http:/ / files.unicef.org/publications/files/Progress_on_Sanitation_and_Drinking_Water_2015_Update_.pdf (accessed on 24 June 2017).

9. Stichting Nederlandse Vrijwilligers. Water Point Mapping: The Experience of SNV Tanzania. Available online: https:/ / www.ircwash.org/resources/water-point-mapping-experience-snv-tanzania (accessed on 28 June 2017).

10. Government of Tanzania launches a nationwide scheme to improve access to water. Available online: https: / / www.gov.uk/government/world-location-news/government-of-tanzania-launches-a-nationwidescheme-to-improve-access-to-water (accessed on 4 July 2017).

11. United Republic of Tanzania. National Water Policy; United Republic of Tanzania: Dar es Salaam, Tanzania, 2012. Available online: http:/ / www.tawasanet.or.tz/ files/Tanzania\%20water\%20policy\%20-\%202002.pdf (accessed on 26 June 2017).

12. Mwamwaja, S.A. Mapping of Public Rural Water Service in Tanzania: A Case of Data Updating. Master's Thesis, University of Twente, Enschede, The Netherlands, 2014. Available online: https://www.itc.nl/library/ papers_2015/msc/upm/mwamaso.pdf (accessed on 28 June 2017).

13. United Republic of Tanzania (URT). Water Sector Status Report 2013; URT: Dar es Salaam, Tanzania, 2013.

14. Pedregal, B.; Cabello, V.; Hernández-Mora, N.; Limones, N.; Moral, L.D. Information and knowledge for water governance in the networked society. Water Altern. 2015, 8, 1-19.

15. Georgiadou, Y.; Bana, B.; Becht, R.; Hoppe, R.; Ikingura, J.; Kraak, M.J.; Lance, K.T.; Lemmens, R.L.G.; Lungo, J.H.; McCall, M.K.; et al. Sensors, empowerment and accountability: A digital earth view from East Africa. Int. J. Digit. Earth 2011, 4, 285-304. [CrossRef] 
16. United Republic of Tanzania. The United Republic of Tanzania-Government Open Data Portal. Available online: http:/ / opendata.go.tz/en/indicator/a2fab64e-47f7--11e5--847d-0e5e07bb5d8a\# (accessed on 1 July 2017).

17. Department for International Development (DFID). Phase Two: Rural Water Supply and Sanitation Programme, Tanzania: Annual Review: Department for International Development. Available online: https: / / www.afdb.org/fileadmin/uploads / afdb / Documents / Project-and-Operations/Tanzania\%20\%20Rural\%20Water\%20Supply\%20and\%20Sanitation\%20Program\%20II\%20_AR_\%20doc\%20+Memo\% 5B1\%5D.pdf (accessed on 27 June 2017).

18. Janus, H.; Keijzer, N. Big Results Now? Emerging Lessons from a Result-Based Aid in Tanzania; German Development Institute: Bonn, Germany, 2015. Available online: https://www.files.ethz.ch/isn/192859/DP_ 4.2015.pdf (accessed on 5 July 2017).

19. Georgiadou, Y.; Verplanke, J.; Lungo, J.; Mbise, M. Water point mapping in Tanzania: Making the voices of data collectors audible. In Proceedings of the 7th Rural Water Supply Network (RWSN) Forum: Water for Everyone, Abidjan, Côte d'Ivoire, 29 November-2 December 2016.

20. Larkin, B. The politics and poetics of infrastructure. Annu. Rev. Anthropol. 2013, 42, 327-343. [CrossRef]

21. Anand, N. Pressure: The polytechnics of water supply in Mumbai. Cult. Anthropol. 2011, 26, 542-564. [CrossRef]

22. Richter, C. Digital Transformations in Indian Cities: Between Paper List and GIS Map; Faculty of Geo-Information and Earth Observation (ITC), University of Twente: Enschede, The Netherlands, 2014. Available online: http:/ / www.itc.nl/library/papers_2014/phd/richter.pdf (accessed on 25 June 2017).

23. See/Saw. Water point Mapping System Review and Data Verification, Draft Final Report, prepared in collaboration with the Ministry of Water, Government of Tanzania and DFID, Tanzania, with support from Crossflow Consulting. 2014.

24. United Republic of Tanzania, Ministry of Water. Tanzania Big Results Now! Road Map National Key Result Area Water 2013/14-2015/16. Available online: https:/ /www.pdb.go.tz/documents/Roadmaps/ 06.\%20Tanzania\%20BRN\%20Roadmap\%20-\%20NKRA\%20Water.pdf and Google Docs Form https:/ / docs. google.com/forms/d/e/1FAIpQLScE5hLf3GFijCHX8xIqHLWiZq3Ok0Y5_it4q10m0a561aAr7A/viewform (accessed on 28 June 2017).

25. United Republic of Tanzania (URT). Water Sector Status Report 2014; Marking the End of WSDP Phase-I. Available online: http:/ /www.maji.go.tz/sites/default/files/u12/WSSR\%202014\%20FINAL_1.pdf (accessed on 7 July 2017).

26. Katomero, J.G. Accountability as an Element of Governmentality: An Investigation of National and Local Executive Accountability Practices in the Water Sector in Tanzania. Ph.D. Thesis, University of Twente, Enschede, The Netherlands, 2017. Available online: https://www.narcis.nl/publication/RecordID/oai: ris.utwente.nl:publications\%2Fb772ad1c-860b-4df0-bc2b-9a2b06a0dc0d (accessed on 10 July 2017).

27. United Republic of Tanzania, Ministry of Water, Rural Water Supply Division. Processes \& Procedures for Updating Rural water point Data in Tanzania: User Manual. Available online: https: / www.maji.go.tz/ sites/default/files/New_UPDATING\%20MANUAL\%20CDMT\%20SEPTEMBER\%202015.pdf (accessed on 11 July 2017).

28. Kühl, S. Organisations: A Systems Approach; Routledge: New York, NY, USA, 2013.

29. Nganyanyuka, K.O. Seeing like a Citizen: Access to Water in Urban and Rural Tanzania. Ph.D. Thesis, University of Twente, Enschede, The Netherlands, 2017. Available online: http://www.itc.nl/library/ papers_2017/phd/nganyanyuka.pdf (accessed on 8 July 2017).

30. Hydén, G. Beyond Ujamaa in Tanzania: Underdevelopment and an Uncaptured Peasantry, London; University of California Press: Berkeley/Los Angeles, CA, USA, 1980.

31. Denzin, N.K. The Research Act; Aldine: Chicago, IL, USA, 1970.

32. Bernard, H.R. Research Methods in Anthropology; Altamira Press: Lanham, MD, USA, 2006.

33. Bowker, G.; Starr, S.L. Sorting Things out: Classification and Its Consequences; MIT Press: Cambridge, UK, 1999.

34. Georgiadou, Y.; Puri, S.K.; Sahay, S. Towards a potential research agenda to guide the implementation of spatial data infrastructures: A case study from India. Int. J. Geogr. Inf. Sci. 2005, 19, 1113-1130. [CrossRef]

35. Pritchett, L.; Woolcock, M.; Andrews, M. Capability Traps? The Mechanisms of Persistent Implementation Failure Working Paper 234; Center for Global Development: Washington, DC, USA, 2010; Available online: https:/ / www.cgdev.org/files/1424651_file_Pritchett_Capability_FINAL.pdf (accessed on 10 July 2017). 
36. Braa, J.; Hedberg, C. The struggle for district-based health information systems in South Africa. Inf. Soc. 2002, 18, 113-127. [CrossRef]

37. Cleaver, F. Development through Bricolage: Rethinking Institutions for Natural Resource Management; Routledge: London, UK, 2012.

38. Cleaver, F.; Franks, T.; Maganga, F.; Hall, K. Institutions, security, and pastoralism: Exploring the limits of hybridity. Afr. Stud. Rev. 2013, 56, 165-189. [CrossRef]

39. Maniatopoulos, G. E-Government movements of organisational change: A social shaping approach. In Proceedings of the 4th International Critical Management Studies Conference, Critique and Inclusivity, Cambridge, UK, 4-6 July 2005; Available online: http:/ / www.mngt.waikato.ac.nz/ ejrot/cmsconference/ 2005/proceedings/movementsmoments/maniatopoulos.pdf (accessed on 11 July 2017).

40. Pelizza, A. Developing the vectorial glance: Infrastructural inversion for the new agenda on governmental information systems. Sci. Technol. Hum. Values 2016, 41, 298-321. [CrossRef]

41. Wesselink, A.; Hoppe, R.; Lemmens, R. Not just a tool. Taking context into account in the development of a mobile App for rural water supply in Tanzania. Water Altern. 2015, 8, 57-76.

42. Fung, A.; Russon Gilman, H.; Shkabatur, J. Six models for the Internet + Politics. Int. Stud. Rev. 2013, 15, 30-47. [CrossRef]

43. Hanseth, O.; Monteiro, E. Understanding Information Infrastructure. Available online: http:/ heim.ifi.uio. no/ oleha/Publications/bok.pdf (accessed on 26 June 2017).

44. Dahlbom, B.; Janlert, S.; Department of Informatics, University of Gøteborg, Sweden. Computer future. 1996.

45. Suchman, L.A. Plans and Situated Actions; Cambridge University Press: New York, NY, USA, 1987.

46. Walsham, G. Interpreting Information Systems in Organisations; Wiley: Chichester, UK, 1993.

47. Ciborra, C.U.; Braa, K.; Cordella, A.; Dahlbom, B.; Failla, A.; Hanseth, O.; Hepso, V. From Control to Drift: The Dynamics of Corporate Information Infrastructures; Oxford University Press: Oxford, UK, 2000.

48. Hyden, G. African Politics in Comparative Perspective; Cambridge University Press: Cambridge, UK, 2004.

(C) 2017 by the authors. Licensee MDPI, Basel, Switzerland. This article is an open access article distributed under the terms and conditions of the Creative Commons Attribution (CC BY) license (http:// creativecommons.org/licenses/by/4.0/). 